\title{
Implementation Of Law Number 11 Of 2012 Concerning Child Related Criminal Justice System Concept Restorative Justice
}

\author{
Intan Karangan \\ Faculty of Law, Hasanuddin University \\ Jl. Perintis Kemerdekaan KM. 10, Tamalanrea, Makassar, 90245, Indonesia \\ Tel./Fax:+62-411-585035 E-mail: E-mail: intankarangan@ymail.com
}

\begin{abstract}
This study aims to determine how the application of the concept of restorative justice in accordance with Law No. 11 of 2012 on Child Criminal Justice system. This study uses normative namely a study that discusses the problem based on the literature and legislation relating to the matter to be investigated. Law No. 11 of 2012 on the Criminal Justice System Child has provided a new concept in the criminal justice system, especially those in the juvenile justice system. Related to the concept of Restorative Justice or restorative justice is a resolution processes involving perpetrators, victims, families, and other relevant parties in a criminal act, jointly seek solutions to the offense and its implications by emphasizing restoration and not retribution.
\end{abstract}

Keywords: Child Criminal Justice System; Restorative Justice

\section{INTRODUCTION}

The criminal justice system of the Republic of Indonesia in a new phase in the development and renewal in the perspective and the achievement of justice to the repair and restoration of the state after the incident and the criminal justice process, known as restorative justice that is different from retributive justice (it stresses fairness in retaliation) and justice restitute (stressed fairness in compensation). ${ }^{1}$

\footnotetext{
${ }^{1}$ Restorative justice views crime as more than breaking the law - it also causes harm to people, relationships, and the community. So a
}

The Republic of Indonesia has ratified the convention on the rights of children through Presidential Decree No. 36 1990. The ratification of this as an attempt of the State to provide protection to children. Children are a part of the citizens who have to be protected because they are a generation of people who in the

\footnotetext{
just response must address those harms as well as the wrongdoing. If the parties are willing, the best way to do this is to help them meet to discuss those harms and how to about bring resolution. Other approaches are available if they are unable or unwilling to meet. Sometimes those meetings lead to transformational changes in their lives.
} 
future will continue the leadership of the nation of Indonesia. Each child in addition to compulsory formal education such as schools, must also obtain a moral education so that the They can grow into a figure that is useful to the nation. In accordance with the provisions of the CRC (Convention on the Rights of the Child), which was then poured in Law - Act No. 4 of 1979 on Child Welfare and Law No. 23 of 2002 on Protection of Children and the Law No. 11 Year 2012 on child Criminal Justice system, all of which suggests the general principles of the protection of children, namely non-discrimination, best interests of the child, survival and development and respect for the child's participation.

Legal protection for children to do as a legal safeguard against the freedoms and rights of children. The protection of children also include interests related to child welfare. Protection of children in conflict with the law $(\mathrm{ABH})$, a shared responsibility of law enforcement officers. Not only children as perpetrators, but also include children as victims and witnesses. Law enforcement officers involved in handling $\mathrm{ABH}$ order not only refers to Law Number 11 Year 2012 on System Criminal Justice System Child or other legislation pertaining to the handling of $\mathrm{ABH}$, but prefers peace than the formal legal process that came into effect 2 SPPA years after the Act was enacted or August 1, 2014 (Article 108 of Law No. 11 of 2012). Therefore, the child as a holder of the baton of the nation's future should be given special protection, given that in childhood is a period of physical growth, character and character therefore very child needs assistance and special attention.

In Indonesia, cases of children in conflict with the law in 2015 is very rampant. How many child juveniles must deal with the law and the question is, how an underage person in the interrogation by the police? And to stand trial in a court? Prison is only appropriate for adults who commit crimes. Kids do not fit in jail and spent his childhood behind bars because it would kill his future. What is needed is a mentoring and coaching. Justice is right for perpetrators of child delinquency is a model that is both justice restorative repair and restore the relationship between the perpetrator and the victim so that harmony is maintained.

To answer various problems in providing protection for children, especially children in conflict with the law, it has on Act No. 11 of 2012 on the Criminal Justice System Centre (UU 
SPPA) that formulate some progress named are:

a) The minimum age for a child can be imprisoned (or hold), which is 14 years old;

b) wearing Restorative Justice approach in the settlement of the child;

c) The existence of qualified law enforcement in handling cases of children;

d) Type of criminal and action;

e) Prohibition to publish the identity of children in conflict with the law.

Related to Restorative Justice approach in the resolution of cases of children is a concept that really should be implemented in order to achieve a legal purpose, namely legal certainty. The concept of restorative justice through Diversion can resolve the case outside the court in terms of the perpetrators, victims, parents of victims and perpetrators as well as other parties who have a role in the daily life of the perpetrator of victims or perpetrators will sit together to discuss the neighbor of the crime and seek the best solution for the sake of the child. After their reports to the local police station or the police station, the police contacted the child Correctional Center to conduct research related data Society victims, perpetrators, and how event can occur arties in this regard Supervisor Community very important role in the process of assisting the child during the investigation, prosecution, and examination in court. In each stage Supervisor community have a duty to assist children in doing.

Diversion. Research Society will be a consideration in making Diversion. To sharpen the legal issues in this article then focused on the issues related to the application of the concept of restorative justice in accordance with Law No. 11 of 2012 on Child Criminal Justice system.

\section{ANALYSIS AND DISCUSSION}

Restorative Justice has expanded globally around the world. In many countries restorative be one of a number of important approaches to crime and justice are continuously considered in the judicial system and law.

Restorative Justice or Restorative justice is a process that involves the completion of perpetrators, victims, families, and other relevant parties in a criminal act, jointly seek solutions to the offense and its implications by emphasizing restoration and not retribution.

Bazemore and Walgrave Lode defines restorative justice as "every action which is basically intended to do / make 
justice by doing repairs for damage caused by a criminal."

Juvenile justice with restorative justice aims to:

a) To strive for peace between the victim and the child;

b) Prioritize the settlement outside the court process;

c) Keep children from the negative influence of the judicial process;

d) Instilling a sense of responsibility for the child;

e) Realizing the welfare of children;

f) Protects children from deprivation of liberty;

g) Encouraging people to participate;

h) Improve the skills of the child.

The idea of restorative justice include in Article 5, that the Criminal Justice System Son shall prioritize restorative justice (paragraph (1)), which include (paragraph (2)):

a) Investigation and criminal prosecution of children carried out in accordance with the provisions of the legislation, unless otherwise provided in this Act;

b) The trial of a child by a court in the general court; and

c) coaching, mentoring, supervision and / or assistance during the implementation process and after a criminal or a sentence or action.

d) And confirmed that the letters a and b must be pursued diversion (paragraph (3)).

Furthermore, article 7 of Law SPPA stated that:

Paragraph (1) "At the level of investigation, prosecution, and the case investigation Children in the district court shall be pursued diversion". Paragraph (2) "Diversion referred to in paragraph (1) shall be implemented in the case of criminal offenses committed:

1. punishable by imprisonment under seven (7) years; and

2. is not a repetition of crime ".

Restorative justice models more efforts on rapprochement between the perpetrator and the victim. For example, a student stole a book professor, how the way of justice process and what steps will be used so that the issue could be resolved. So that the good relationship between students and professors took place as before without being harmed.

According to the model of restorative, child delinquency behavior is behavior directed at the improvement of the loss and wound healing in the community. Restorative justice is not to be punitive nor mild nature. Its main objective 
is the improvement of the injuries suffered by the victim, the perpetrator recognition of the injuries suffered by the victim, the perpetrator recognition of the injuries caused by his actions and conciliation and reconciliation among victims, offenders and the community. Also intends to restore the welfare of society through means confronts the child's behavior on the responsibility for his behavior, victims should have a role in the judicial process.

Juvenile justice model of restorative justice also start from the assumption that the response to child delinquency reaction is not effective without the cooperation and involvement of the victim, offender and community. The fundamental principle is that justice is best served if each party receives attention in a fair and balanced, actively involved in the judicial process and to benefit adequately from their interaction with the juvenile justice system.

Helen Cowie and Dawn Jennifer (2007) identify key aspects of restorative justice as follows:

a. Repair, not about obtaining a victory, or accept defeat, accusations or retaliation Interest SPPA with Restorative Paradigm

The purpose and rationale of the juvenile criminal justice can not be left of the ultimate goal is to realize the child prosperous which basically is an integral part of social welfare. In the juvenile justice system with Restorative paradigm in achieving the objectives of sanctions, it included the victim's right to be involved in the judicial process. Indicators of achievement of the objectives of sanctions achieved by seeing whether the victim had been restored, the satisfaction of the victim has been restored, much in damages to the victim, and the circumstances of the perpetrator awareness of his actions.

\section{b. Diversi}

The word is derived from the English diversion Diversion which means "diversion". Based on General Guidelines Indonesian Enhanced Forming Terms and General Guidelines, adjusted in Indonesian be Diversion. According to Romli Artasasmita, Diversion is the possibility of a judge to stop or divert / do not pass on the case investigation and examination of the child during the examination process upfront trial.

In this discussion, will be described some theories of punishment and sentencing the real purpose for what it is 
dropped. According Wirdjono Prodjodikoro purpose of sentencing is to satisfy the justice. In criminal law, the theory of punishment is divided into three (3) categories, namely:

1. The theory of absolute (vergeldingstheorien) adopted by Immanuel Kant argued the purpose of sentencing as a retaliation against the perpetrators for committing a crime that resulted poverty against another person or the community members.

2. Teorirelatif (doeltheorien) based on the destination (doel) as follows:

3. Be wary of the expected sentencing convicted offenders or be deterrent and not repeat his actions and the general public can know that if done the deed will receive similar punishment.

4. Improve Personal convicted in treatment and education provided for serving a sentence, the convict felt sorry that he will not repeat the act and return to the community as a good and useful.

5. Combined Theory / Modern (Vereningingstheorien) whose adherents are Van Bemmelen and Grotius focusing absolute justice embodied in retaliation, but useful for society. Basic every criminal is suffering severe in accordance with the severity of acts committed by the convict. But to what extent and severity of the severity of the criminal acts committed by the convict can be measured and determined by what is good for society.

Another theory is associated with criminal sanctions proposed by Jeremy Bentham in the utilitarian view, that punishment must be specific for each crime and violent crime can not exceed the amount necessary to prevent the perpetration of a specific attack.

Punishment is only justified if it gives hope to avoid a greater evil. Based on some theories of punishment above, it can be said that basically Diversion have relevance to the objective of sentencing a child, which appears on the following matters:

1. Diversion as the diversion of judicial process to non-judicial process, intended to avoid the child from the application of criminal law that often cause a bitter experience in the form of stigmatization (negative cap) prolonged, dehumanization (alienation from society) and prevent children from the possibility of being 
prisonization transfer means crimes against children.

2. Deprivation of liberty of children in the form of imprisonment or other deprivation in the form of through criminal justice mechanism, giving a traumatic experience for the child, so the child distracted the development and growth of his soul. The bitter experience of contact with the world of justice will be the dark shadow the lives of children who armpits easily forgotten.

3. With the Diversion the children avoid the application of the criminal law in many theories have been postulated as one of the factors kriminogen, means also prevent children from the possibility of being nasty back (residive), prevent people from becoming a victim of crime as a result.

4. Diversion will provide two (2) at the same advantages for the individual child. First; children can stay in touch with their environment, so no need to adapt the social aftermath of the crime. Second; children avoid negative impacts prisionization which is often a means of transferring a crime.
In Article 1 paragraph 7 of Law SPPA mentioned Diversion is the transfer of the settlement Son of the criminal justice process to the judicial process outside law, SPPA Law has set about Diversion which serves to children in conflict with the law are not stigmatized as a result of the judicial process that must be lived. The use of the diversion mechanism provided to law enforcement (police, prosecutors, judges, other institutions) in dealing with offenders law involving a child without using a formal court. Application of Diversion is intended to reduce the negative impact of children's involvement in a judicial process.

Diversion is a settlement of cases of children who are suspected of certain crimes from the formal criminal to a peaceful settlement between the suspect / accused / offender with the victim facilitated by family and / or community, Supervisor of Community Child, the police, prosecutors or the judge. diversion is the transfer of the settlement Kids diversion from the criminal justice process to a process outside the court.

Diversion aims:

a) Achieving peace between victims and Children.

b) Completing Kids case outside the judicial process. 
c) Protects Children of deprivation of liberty;

d) Encouraging people to participate; and

e) Instill a sense of responsibility to the Son.

Diversion process shall take into account:

a) The interests of the victim;

b) Child Welfare and responsibilities;

c) avoidance of negative stigma;

d) Avoidance of retaliation;

e) The harmony of society; and

f) Decency, morality and public order.

The results can take the form of diversion agreement, among others:

a) Peace with or without compensation;

b) Submission back to the parents / guardians;

c) Participation in education or training in an educational institution or LPKS later than 3 (three) months; or

d) Community service.

In terms of assistance in the process of Diversion Kids at this stage of investigation, prosecution and court examination of each in every stage will be made an official report. Diversion is done twice in each stage, if the diversions carried out at the level of investigation and did not reach an agreement then it will be taken up again in diversion for the second time. If the second attempt Diversion and Diversion did not reach agreement then declared a failure, then the police will bestow the file to the prosecution stage at the AGO.

Diversion is the Son of the transfer case to the criminal justice process outside the criminal justice process. Under the provisions of Article 8 of Law SPPA, Diversion process is done through consultations involving a child and a parent / guardian, victim and / or the parent / guardian. Supervising Social and Professional Social Worker based Restorative justice approaches. Investigators, public prosecutor, and the judge in the implementation of Diversion should consider the categories of crime, the age of the Son, the environment, family and social research results from the Child Community.

Based on the results of the research community, the Bapas will give recommendations on the type of agreement Diversion conducted by investigators to resolve the children case. For implementation period Diversion the hearing, set out in Article 53 of Law SPPA which states that the diversion referred to in paragraph (2) shall be implemented at the latest 30 (thirty) days. In practice, it could be after the expiration of 30 (thirty) 
days, or after a trial lasting turns out the victim's and Children obtain an agreement to make peace. In this case, the judge must first look at the shape of the peace made, if it is only forgive the mistakes of the Child but want the legal process is still running, then the attitude of the judge is continuing the trial. The pardon of the victims / families will be considered as mitigating Children in imposing sentence. If in peace the victim requested that the examination of his case is stopped, then it is wiser if the case was halted by the judge and the judge deliver Minutes Diversion Agreement together with the Chairman of the Court for Determination issued. This is presumably in line with the spirit of Law SPPA which restorative justice through diversion.

Diversion have reached an agreement, Supervisor Community will continue its oversight of the form of the agreement. And if in case of diversion had not reached a deal so it still be continued at a later stage. According to article 14 paragraph (2) of the SPPA, in this case Diversion not implemented within the time specified, social counselors shall immediately report to the responsible authorities referred to in paragraph (1) .As for the forms of the agreement if it can successfully Diversion either replacement of the goods in case of theft, stolen goods are replaced by the perpetrator. Medical expenses for victims of traffic accidents and mistreatment or beatings.

In the level of investigation and prosecution, investigators and prosecutors need to get the diversion to the Chairman of the District Court for the next Chairman of the Court will issue a determination and based on that definition, then the investigator will issue a determination of termination of the investigation, while the public prosecutor will issue a determination of termination of prosecution.

A little look back in the setting of SP3, in Article 109 paragraph (2) Criminal Procedure Code which states: "In the case of investigators to stop the investigation because of insufficient evidence or the incident was not a criminal offense or the investigation terminated by operation of law, the investigator notify the public prosecutor, the suspect or his family ".

Furthermore, based on the Criminal Code, there are two (2) reasons as the basis for the public prosecutor terminate the prosecution of the cessation of prosecution due to technical reasons and the termination of prosecution for policy reasons. The authority does not demand as the reason for their technics there are 3 
(three) state as stipulated in Article 140 paragraph 2 letter a Criminal Code, as follows:

1. If there is sufficient evidence;

2. If the event is not a crime;

3 . If the case is closed by law;

The authority does not demand for policy reasons because the Attorney is authorized to waive the case. The authority is exercised in the public interest, the interests of the individual and the principle opportunities. Under the draft is not stated explicitly, but in the explanation of Article 77 of the Criminal Procedure Code implied that the Attorney General's authority was recognized, namely to set aside the case.

Determination of the Chairman of the District Court Diversion under examination in court stipulated in article 52 paragraph (2) "Judges shall endeavor Diversion of 7 (seven) days after adoption by the chairman of the district court as a judge". Paragraph (3) "Diversion referred to in paragraph (2) shall be implemented no later than 30 (thirty) days". Paragraph (5) "In terms of the process Diversion managed to reach an agreement, the judge delivered the news event along Diversion agreement to the chairman of the district court to make the determination."

In paragraph (5) provides that judges communicating the results to the Chairman of the Court Diversion for Determination issued. Determination is a new and different things with the arrangements as existed before because it involves the status quo case. According to the author, the content / substance stipulation essentially establishes that the parties implement the results of Diversion, the official in charge of the case is to immediately issue a Warrant Termination of Investigation (SP3) or an assessment letter Cessation of Prosecution (SKPP) or Stipulation termination examination of the case a quo and ordered the Clerk to send a copy of such determination to the parties concerned (investigator, prosecutor, judge, social Supervisor).

Another problem that can arise is, what if the agreement is not implemented Diversion while the case has been terminated the process, for example, the offender must pay the amount of compensation to the victim but the perpetrator then not be able to pay, whether the case can be reopened its legal process ?, using instruments civil law on the basis of default would seize quite a long time, so there may be a psychological disturb the child because it is always associated with the trial.

Under the provisions of article 13 paragraphs $b$ states that the judicial process 
is continued if the diversion agreement is not implemented. Article 14 paragraph (3) states In case the agreement Diversion not implemented within the stipulated time, supervisor of Society immediately reported to the responsible officials referred to in paragraph (1), hereinafter in paragraph (4) Officer in charge referred to in paragraph ( 3) shall follow up the report within a period of 7 (seven) days. Only the problem is how the mechanism if the trial reopened ?, this needs to be further regulated in Government Regulation on the Implementation Procedures Diversion or in the technical guidelines of the respective levels, investigation, prosecution and court examination.

Punishment for criminal Children do not then achieve justice for the victims, given from the other side is still leaving its own problems are not resolved even though the offender has been convicted. See the principles of child protection particularly principle that the best interests of the child it is necessary to process the solution case children outside the criminal mechanisms or so-called Diversion. Institutions punishment is not the way to solve the problem of youth because even in it prone to abuses-a violation of children's rights.
Obstacles in implementing the peace between victims and perpetrators often been based on the attitude of law enforcement is very formalistic, saying the legal process will continue to run even if there has been a peace, nature against the law will not be clear for peace. According to Bagir Manan S.H, MCL, is there objective of sentencing is not yet achieved if the parties have united to each other? The purpose of law enforcement is not to apply the law, but rather to achieve order, peace, tranquility, in a society harmonious and fair.

\section{CLOSING}

\section{Conclusion}

In the case of Children in Conflict with the Law is necessary to pay attention to the principle of the best interests of the Child, as well as the condemnation process is a last resort (ultimum remedium) with fixed.

The concept of Restorative Justice in settling disputes through Diversion children who have been regulated in the Act SPPA, the application is not running properly. Many factors influence. That must be noticed that the interests of the victim, whether as Diversion have managed to reach an agreement has been able to meet victims' recovery back to the original condition. For example in the case 
of immoral, they rarely reach an agreement, because in cases immoral to calculate the amount of compensation can not be calculated because it concerns someone disgrace. The victim or the victim's family is not uncommon that would make peace or compensation. So it is not fulfilled the rights of victims and Diversion considered unable to reach agreement and proceed to the next stage.

\section{Suggestion}

Based on the results of the study authors have summarized in the above conclusions, the authors recommend some of the following:

1. The need for good coordination of all parties involved in the implementation of Diversion, between the police with the Bapas the results of the research community.

2. The need for the government in this case the Ministry of Social Affairs for the recovery of victims will pay attention in particular to the victims of the crime of fornication.

3. The need to provide guidance specific to the offender. If the offender is returned to the parents should still get more scrutiny, so that the perpetrators avoid the risk of repetition of criminal acts.

\section{BIBLIOGRAPHY}

Amir Ilyas, Principles of Criminal Law, Understanding Crime and Criminal Liability For Terms Punishment (Accompanied Theories Introduction and Some Comments). Yogyakarta: Rangkang Education.

Juhaja S Praja. (2011). Legal Theory and Applications. Bandung: Faithful Reader,.

Kusno Adi. (2009). Diversi As Alternative Efforts Combating Crime Narcotics By Kids. Malang: UMM Press.

Marlina. (2012). Konsep Diversi Dalam Peradilan Pidana Anak di Indonesia. Bandung: PT Refika Aditama.

Muladi and Barda Nawawi Arief. (2007). Kebijakan Hukum Pidana. Bandung: P.T. Alumni.

Ridwan Mansyur. (2014). As of Interest Implementing Restorative Justice in the Criminal Justice System Diversi Kids. Jakarta: Rajawali Press.

Setya Wahyudi. (2011). Implementasi Diversi Dalam Sistem Peradilan Anak di Indonesia. Yogyakarta: Genta Publishing. 